\title{
Awakening sociocultural realities in pre-service teachers through a pedagogy of multiliteracies $^{1}$
}

Despertar las realidades socioculturales en los profesores en formación a través de una pedagogía de las multiliteracidades

\section{Angela Yicely Castro Garcés ${ }^{2 *}$}

Universidad del Cauca, Colombia

1 Received: April 14th 2020 /Accepted: May 14th 2021

2 aycastro@unicauca.edu.co 


\section{Abstract}

Language learning that is grounded on learners' sociocultural realities promises to be a meaningful experience they are likely to treasure when it comes to grappling with practical day-to-day matters. This article reports on a research study aimed at fostering socioculturally constructed language learning in a group of pre-service English teachers. This is a qualitative case study, grounded in a social constructivist paradigm, which draws on a pedagogy of multiliteracies through the Knowledge Process and the Concept of Design (Cope \& Kalantzis, 2009) to embrace diverse modes of communication and to expand learners' possibilities of engagement with text and the social and cultural world around them. The findings indicate that while learners are provided with opportunities to explore, reflect and co-construct socioculturally driven knowledge, they are involved in a meaning-making experience that allows them to make sense of the language they are learning. In this way, participants embraced diversity and gained sociocultural understandings by engaging in a pedagogy of Multiliteracies.

Keywords: Sociocultural realities, pedagogy of multiliteracies, pre-service teachers, language learning, design

\section{Resumen}

El aprendizaje de una lengua basado en las realidades socioculturales de los educandos promete ser una experiencia significativa que han de atesorar cuando traten de resolver asuntos prácticos de la vida diaria. Este artículo reporta una investigación cuyo objetivo fue fomentar el aprendizaje de una lengua construido socioculturalmente en un grupo de profesores de inglés en formación. Este es un estudio de caso cualitativo apoyado en el paradigma constructivista social, el cual toma como base la pedagogía de las multiliteracidades a través de los Procesos de Conocimiento y el Concepto de Diseño (Cope y Kalantzis, 2009) para incluir diversos modos de comunicación y ampliar las posibilidades de compromiso de los estudiantes con el texto y el mundo social y cultural que los rodea. Los resultados indican que mientras los estudiantes tienen la oportunidad de explorar, reflexionar y co-construir conocimiento promovido socioculturalmente, ellos a la vez se involucran en una experiencia de construcción de significado que les permite dar sentido a la lengua que están aprendiendo. De este modo, los participantes dieron la bienvenida a la diversidad y adquirieron conocimientos socioculturales al involucrarse con una pedagogía de las multiliteracidades.

Palabras clave: Realidades socioculturales, pedagogía de las multiliteracidades, docentes en formación, aprendizaje de lenguas, diseño 


\section{Resumo}

Aprender uma língua com base nas realidades socioculturais dos aprendentes promete ser uma experiência significativa a ser valorizada quando se lida com questões práticas da vida quotidiana. Este artigo relata uma investigação que visava fomentar a aprendizagem sociocultural de línguas num grupo de professores estagiários de língua inglesa. Este é um estudo de caso qualitativo apoiado pelo paradigma construtivista social, que se baseia na pedagogia multiliteracional através de Processos de Conhecimento e do Conceito de Design (Cope \& Kalantzis, 2009) para incluir diversos modos de comunicação e expandir as possibilidades de envolvimento dos estudantes com o texto e o mundo social e cultural que os rodeia. Os resultados indicam que enquanto os estudantes têm a oportunidade de explorar, refletir e co-construir conhecimentos promovidos socioculturalmente, eles ao mesmo tempo dedicam-se a uma experiência de criação de sentido que lhes permite dar sentido à língua que estão a aprender. Desta forma, os participantes acolheram a diversidade e ganharam conhecimentos socioculturais ao envolverem-se com uma pedagogia de multiliteracias.

Palavras chave: Realidades socioculturais, pedagogia do multiliteracia, formação de professores, aprendizagem de línguas, design 


\section{Introduction}

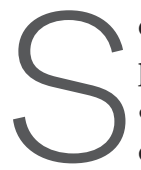

ociocultural views of literacy ingrained in meaning constructed in social practice (Street, 2013) have expanded the monolingual, monocultural (Cope \& Kalantzis, 2000) view of reading and writing, favoring a multiplicity of discourses and welcoming diverse modes of communication. The foreign language classroom has also been viewed as a space beyond verbocentricity (Alvarez Valencia, 2016; Kress, 2000), in which multiliteracy (ML) practices (Cope \& Kalantzis, 2009; The New London Group (NLG), 1996) are to be welcomed. Language is thus approached not as the ultimate goal, but as a means for building relationships and making meaning out of experiences lived inside and outside the classroom.

Technology and the new communication landscape have opened avenues for New Literacies (Gee, 1996; Knobel \& Lankshear, 2007; Perry, 2012). These new ways of acting in the world and with the world have reconceptualized what literacy practices are, how they interact and intersect in social events, requiring a different type of engagement with text or, as NLG (1996) posits it, a ML practice. A ML perspective implies a pedagogical approach to literacy (NLG, 1996) that brings possibilities for more inclusive, cultural, linguistic, communicative, and technological diversity in the classroom.

The main contribution of this study is to take on a pedagogy of ML that helps awaken sociocultural realities in pre-service English teachers (PTs). This is done through the Knowledge Process, by means of which they will experience, conceptualize, analyze and apply knowledge gained, at the same time that they are able to use available designs and redesign (Cope \& Kalantzis, 2009) based on their meaning making experiences.

The studies reviewed in the area of ML (Cope \& Kalantzis, 2000, 2009; Kalantzis \& Cope, 2004, 2008; NLG, 1996) help in the conceptualization to favor language learning that is context-sensitive (Kumaravadivelu, 2001), makes meaning through various modes of communication (Kress, 2010), goes beyond print literacy, and considers diverse semiotic systems (Cope \& Kalantzis, 2009; O’Rourke, 2015; Perry, 2012).

This qualitative case study (Merriam, 2009), grounded in a social constructivist paradigm (Hua, 2016), aims at fostering socioculturally constructed language learning through a pedagogy of ML. This research is developed with a group of fourteen PTs to help them build a much more meaningful language learning experience. It attempted to answer the following research question: To what extent does a pedagogy of ML contribute to fostering socioculturally constructed language learning?

Following, I present studies on literacies and ML, the research design, findings, conclusion and pedagogical implications. 


\section{Literacies and Multiliteracies}

So-called literate Western societies have for too long insisted on the priority of a particular form of engagement, through a combination of hearing and sight: with the sense of hearing specialized to the sounds of speech, and the sense of sight specialized to the graphic representation of sounds by "letters", on flat surfaces (Kress, 2000).

The quote above illustrates a critique to the mere focus on print literacy practices, this is why I consider it a good start for building on the background of literacy. This section attempts to survey the evolution from traditional literacies to multiliteracies, in order to understand and reflect upon the changes undergone by this discipline, and to elucidate its implications for this classroom-driven research.

\section{Literacy}

Literacy, defined by Street (2013) as social practices of reading and writing, has undergone shifts with the advance of technology, the different sociocultural changes of a globalized and globalizing world, and the recognition of the role of different modes of communication in the construction of meaning. Nevertheless, its early development was situated between the cognitive (text-level reading comprehension and its linguistic components) and social practices (what readers can do with the texts they approach). Street, as an advocate for reading and writing that has a purpose on people's lives, contrasted autonomous and ideological models of literacy. The autonomous model assumed literacy to be a set of neutral, decontextualized skills that can be applied in any situation. Literacy is something that one has or does not have; people are either literate or illiterate, and those who are illiterate are deficient. He also advices on the need to avoid such an autonomous model. The ideological model, on the other side, conceptualizes literacy as a set of practices ground in specific contexts. Perry (2012) suggests that "literacy as a situated social practice underpins other theories within the larger umbrella of sociocultural theories on literacy" (p.53). In point of fact, giving context a starring role, recognizing students' realities and background, as well as listening to their voices is essential for meaningful teaching and learning to take place (Ausubel, 1963; Kumaravadivelu, 2001, Mora, 2011).

Additionally, Barton and Hamilton (2000) differentiate between literacy events and literacy practices. They describe events as "observable episodes which arise from practices and are shaped by them" (p. 8); that is, the evidence of people approaching literacy. Practices, in contrast, can be rather unobservable, intangible. Barton and Hamilton (2000) define practices as "the general cultural ways of utilizing written language which people draw upon in their lives. What people do with literacy" (p. 8). Thus, how people approach literacy has to do with the practices established, 
including power relationships, access to literacy, and the kind of literacy that is related to a specific system of values. Although there may be good in each of the concepts, literacy events and practices are presented as dichotomies in literacy, or extreme forces mediating literacy, which in the pedagogical arena places teachers in a decisionmaking situation because one is usually presented as bad, traditional, non-social and unrecommendable. Our pedagogical practice and research in the classroom will need to ponder situated practices in order to mediate between the two edges, which can be rather complementary. As Mora (2011) argues, "in order to really understand how literacy beliefs and practices continue evolving, it is not just to conceptualize it from theory or from pedagogy" (p. 3).

Subsequently, Mora (2011) points at the difficulty of using the word literacy and establishing its clear meaning, but argues that one meaning that is commonplace among scholars is: "The transition from traditional canonical views of reading and writing to one where multiple forms of expression, technology, alternative and multicultural text have come into play" (p. 3). This is a view that expands our notion of literacy to an inclusive practice derived from the learners' needs, which can only be possible through the consideration of their own realities, contexts and life experiences.

Furthermore, Cope and Kalantzis (2000) question the fact that "literacy pedagogy has traditionally meant teaching and learning to read and write in page-bound, official, standard forms of the national language" (p. 9); therefore, they "attempt to broaden this understanding of literacy and literacy teaching and learning to include negotiating a multiplicity of discourses" (p. 9). Their approach to literacy provides a broader perspective that includes multiple modes of communication for a multisensory experience at the same time that it considers globalism and diversity. They argue that "we are agents of meaning-making, thus it is essential to use a didactic literacy pedagogy that proposes a deeper approach to reading and interpreting meaning; a much more dynamic view of literacy that considers the design of a variety of texts and ways of communicating" (p. 12). Accordingly, as the study of literacy has embraced multimodality (MM), it has brought the school and home contexts together, permeating social aspects that traditional literacy did not consider. Rowsell and Collier (2017) assert that MM "explains communication as a combination of modes of representation and expression within text designs, including visual, print, gestural, dramatic and oral" (p. 313).

There have been studies about literacies developed in the national Colombian context which urge to develop literacy practices that include local knowledge (Sharkey, 2012) and raise awareness on social and educational issues (Clavijo, 2000, 2003, 2007; Correa, 2010; Mora, 2011, 2012, 2014, 2015, 2016; Rincon \& Clavijo, 2016). Clavijo (2000) as well as Mora (2011) have led the study of literacies, generating in-depth reflection on literacy practices in Colombia. In fact, Clavijo $(2000 ; 2007)$ has inquired into the role of literacy at different levels of education, reflecting upon primary school 
students, pre-service, and in-service teachers' understandings of literacy practices and the need to integrate school subjects to nurture more meaningful literacy practices. Her studies extoll school teachers' work on literacies and how these permeate the school and social contexts, advocating for students' learning needs and sociocultural realities. Likewise, Mora (2011) analyzes the evolution of literacy beliefs and practices of teachers and the need to rethink educational practices; reflect upon understanding the concept of literacy, its historical and pedagogical evolution in teachers and students.

There is also a call for literacy with a purpose, to reflect upon critical consciousness, ideology in textbooks and to foster agency, including city literacies that transform individuals through reflection and advocacy (Mora, 2014, 2015, 2016). Rincon and Clavijo (2016) implemented Community Based Pedagogies as a way to bring literacies closer to students" local realities. They affirm that "the inquiry that students did in their communities unfolded a wide variety of multimodal ways to represent their findings" (p.77), which allowed for meaningful and more context-based language learning. Similarly, Sharkey (2012) discusses teachers' reflection about local realities as a must, in times of educational reforms. She views "language and literacy as situated, cultural practices" (p. 11), thus aligned to students' sociocultural realities, voiced through literacy practices (Rincon \& Clavijo, 2016).

Literacy can be viewed as the door through which knowledge, critical thinking, and interpretation of reality is possible if we wish our students to become more intercultural, propositive and reflective citizens. In my view, literacy has to serve a social and reflective purpose inside and outside the classroom. It is not merely about decoding words to 'understand' a text meaning, but it is about using that text to solve real-life situations.

\section{Multiliteracies}

ML is a pedagogical approach to literacy developed by the NLG in 1996, which aims to make classroom teaching more inclusive of cultural, linguistic, communicative, and technological diversity. The NLG used the word ML under two important premises: "The multiplicity of communication channels and media, and the increasing salience of cultural and linguistic diversity" (Cope \& Kalantzis, 2000, p. 5). The goal was to find alternative ways in which literacy pedagogy could fit the changing contexts and realities of today's learners through empowerment and critical decision-making. Cope and Kalantzis (2000) argue that "mere literacy' remains centered on language only... while a pedagogy of ML, by contrast, focuses on modes of representation much broader than language alone, which differ according to culture, and context, and have specific cognitive, cultural, and social effects" (p. 5). 
NLG suggests four components of pedagogy as follows: "Situated practice, Overt instruction, Critical Framing, and Transformed Practice" (1996, p. 7). These dimensions bring ML closer to the language classroom as they embrace linguistic and non-linguistic aspects, contextual teaching and learning through meaning-making that is considered essential to be able to design our learning experience.

In addressing the question of the 'what' of literacy pedagogy, NLG (1996) proposes a metalanguage of ML based on the concept of 'Design'. Teachers are seen as designers of learning processes and environments. They need creative intelligence to redesign their activities in the very act of practice. Learning and productivity are the result of the designs (structures) of complex systems of people's environments, technology, beliefs, and texts (p. 19). A pedagogy of ML, and the concept of design are essential elements for the development of this study because they build the conceptual and instructional framework to help PTs make meaning out of ML practices and potentially develop sociocultural awareness.

According to the researchers of NLG (1996), ML "overcome the limitations of traditional approaches by emphasizing how negotiating the multiple linguistic and cultural differences in our society is central to the pragmatics of the working, civic, and private lives of students" (p. 60). Michelson and Dupuy (2014) back up this idea through the development of a project based on a pedagogy of ML in a language class. They suggest that "ML pedagogies have been taken up both as curricular reform projects as well as instructional techniques" (p.25). Adding to this, social semiotics is important to the world of ML as an approach to communication that seeks to understand how people communicate by a variety of means in particular social settings. Michelson and Alvarez Valencia (2016) affirm that "social semiotics delves into how meanings are made and structured in processes of communication and semiotic acts and products are constituted and shaped through historical, cultural, and social uses of signs" (p.2). One essential aspect of social semiotic theory is the principle that modes of communication offer historically specific, socially and culturally shared options or semiotic resources for communicating (Kress, 2010; Kress \& Van Leeuwen, 2001).

Research done in the area of ML has permeated first and second language acquisition, as well as a variety of contexts. Works developed in students' first language (Hepple et al., 2014; Kim \& Omerbašić, 2017; Luke, 2000; Meng, 2016) have implemented pedagogical practices that consider technology, literature, and social realities to provide meaningful pedagogical experiences. Moreover, the foreign language teaching field has benefited from the advances in ML for students' critical engagement and cultural awareness (Boche, 2014; NLG, 1996; Dooley, 2009; Freedman \& Carver, 2007; Fukunaga, 2006; Jacobs, 2013; Michelson, 2018; Michelson \& Dupuy, 2014; Olthouse, 2013). Other works that have considered a pedagogy of ML have integrated digital practices (Amicucci, 2014; Carita, Mäkinen \& Coiro, 2013) and sociocultural realities (Cridland-Hughes, 2012; Curwood \& Cowell, 2011; De la Piedra, 2010), including the 
project carried out by Nieto (2018) who suggests the integration of students' realities based on a theory of community-based pedagogies.

In the local Colombian context, some studies have drawn on a ML perspective (Alvarez Valencia, 2016; Areiza et al., 2014; Losada \& Suaza, 2018; Medina et al., 2015). In this way, Colombian authors have explored a ML approach from a community perspective to make sense out of reading practices that include technology and diverse social semiotic resources toward the construction of meaning (Alvarez Valencia, 2016; Areiza, et al., 2014; Lozada \& Suaza, 2018). As an example, Medina et al. (2015) turn to ML to help their students read their communities critically so as to transform their lives. The previous studies are meaningful illustrations of how the foreign language classroom has become a vehicle to explore students' realities through meaningful context-driven ML practices.

\section{Research Design}

This study is grounded in a social constructivist paradigm, for meaning is constructed subjectively and "intercultural differences and cultural memberships are socially constructed” (Hua, 2016, p. 12). This view aligns with the idea of learning for life and the construction of knowledge through experience (Honebein, 1996). Social constructivism, as an epistemological perspective, informs this study because it nurtures participants' knowledge construction, based on their sociocultural realities, by engaging them in ML practices.

This study is carried out based on a pedagogy of ML (Cope \& Kalantzis, 2009; NLG, 1996), in which the enormous shifts in the ways in which people make meaning in the contemporary communications environment are accentuated. As such, a ML perspective is underpinned by a social constructivist epistemology, given it understands learning as a negotiation and construction of meanings. This work is approached from a qualitative interpretive case study perspective to gain a deep understanding and provide a "detailed description and analysis" (Creswell, 2012, p. 481) of the understanding participants have, while experiencing a pedagogy of ML, fostered in their sociocultural realities. In this line of thought, Guba and Lincoln (1994) argue that "qualitative data can provide insight into human behavior" (p. 106). Moreover, Merriam (2009) presents case study as "one type of qualitative research that searches for meaning and understanding; the researcher being the primary instrument of data collection and analysis. A case study is an in-depth description and analysis of a bounded system" (p. 39-40). The bounded system in this research is the specific group of PTs who make part of this study. 


\section{Context and participants}

This study was carried out during an academic term at a State University in Colombia with a group of fourteen PTs who were part of a reading class. Some of the activities developed during the academic term were part of the data collection instruments, therefore, everyone enrolled in the course participated in the study. Nonetheless, participants signed an informed consent form in which they were explained about the data that would be collected out of the activities developed and how their anonymity would be ensured. The group was made up of nine women and five men, and their ages ranged between 18 and 24 years old. My positionality as a teacher-researcher was that of a participant observer, helping PTs in their meaning-construction experience; I was also involved in proposing, designing and developing ML activities with them and in collecting evidence that helped answer the research question of the study.

\section{Data collection instruments}

I collected data during an academic term, in which I built on PTs' concept of ML and the rationale behind it. Then, I drew on a pedagogy of ML through the Knowledge Process $^{3}$; reframed by Cope and Kalantzis (2009) into acts for learning, as follows: Experiencing (becoming immersed in new situations); Conceptualizing (connecting concepts); Analyzing (evaluating one's perspectives); and Applying (putting knowledge into practice) (See figure 1), while encouraging participants to explore, reflect, and enact new knowledge. Additionally, the concept of design gave participants tools to put ML into practice, while using available designs or redesigning, based on their own interests and needs.

The following activities allowed for data collection that was later on interpreted through content analysis (Patton, 2002), in order to organize, document and analyze participants' meaning construction processes. (1) Scaffolding on ML: This was made up of two articles and a video to know the critical and contextual tenets of literacy (Perry, 2012), as well as the "why", "what" and "how" of ML (Cope \& Kalatzis, 2009), and the resources and possibilities that a pedagogy of ML brings to a language class. (2) Imagery: A series of images to notice, describe, and voice sociocultural realities (Corbett, 2010). (3) Reading our campus: Noticing literacies written through graffiti, poetry, drawings, and other artifacts. (4) Survey: To unveil perceptions from the reading our campus project.

3 NLG original terminology: "Situated practice, Overt instruction, Critical Framing, and Transformed Practice” (1996, p. 7). 


\section{Findings}

Learning is to be related to context and reality, thus grounded on specific needs for it to be a meaningful experience; this is why, language teachers are encouraged to see the particular, practical, and possible (Kumaravadivelu, 2006), or the sociocultural realities taking place in our classrooms. That is, our philosophy of language teaching and learning is to inform our dos in the classroom, always including students as agents who can contribute to their own learning processes. Following, I present a descriptive, then analytic discussion of each of the moments of the study:

Scaffolding on ML - We read the article What is literacy (Perry, 2012). This was the first approximation to the topic and allowed participants to understand how literacy practices are to be mediated by our sociocultural endeavors, presented in a variety of modes and thought of in a critical manner to deconstruct paradigms and re-construct realities, based on the readers' schemata. As teachers to be, one important element we drew upon was literacy instruction, which started raising awareness on how we access and process information and how we could help others do the same.

Following, we read $M L$, new literacies, new learning pedagogies (Cope \& Kalatzis, 2009), which is concerned with new approaches to literacies teaching and learning. Within an educational perspective, the authors establish the "why", "what" and "how" of ML and present a broad landscape which allowed PTs to reflect upon the benefits of adopting a pedagogy of ML; that is, not only for their current language learning process, but also for their future as teachers. This last article was accompanied by the video Representation, communication and design, which is one of a series of videos that Cope \& Kalantzis present to illustrate on ML and the concept of design. This one was chosen in particular because it does a good liaison between ML and the concept of design, and provides an overview of how we approach texts, and understand them, using all our senses and schemata.

Imagery - Following Corbett's (2010) intercultural language activities, PTs were exposed to a series of images to make them reflect about sociocultural realities. They discussed how each image could potentially describe reality, and in which specific contexts. This generated class discussion and participants were able to voice their perceptions about the images they observed. I named each image as a probing question, then I proposed to reflect upon the topic through a think, pair, share activity. This allowed participants to first think to themselves, then get in pairs to compare their initial ideas and build arguments to support their views; and then, as a group, share their positions in front of the class. 
Figure 1. Have you ever experienced this?

https://blogs.iadb.org/igualdad/wp-content/uploads/sites/33/2020/01/caricatura-meritocracia. jpg

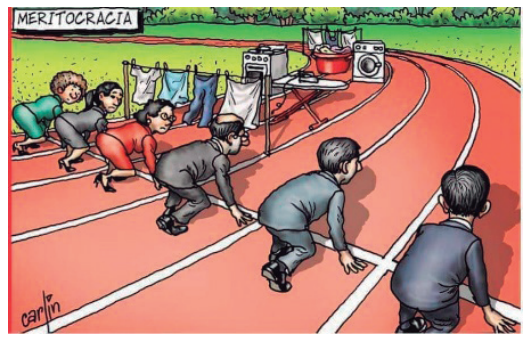

Female participants, eager to indicate women's role in today's society, mostly led the discussion. I selected some of their comments, which they provided to illustrate the slight changes we have experienced in gender roles from previous generations to today, nonetheless remarking the commonly heavier load women still have today. They stated: Women find more obstacles than men because the later commonly find the road clearer. Regarding job search, women sometimes are not hired because they have kids, thus they might get late to work or because the maternity leave is longer now. Even if we do not have kids, we have to wash our own clothes, cook, clean our rooms, and so on; men, however, usually rely on a woman to do that. There is usually their mom, an aunt, grandma, or someone there to help them.

Another view point was mentioned: I have a different experience. I have my mom, dad, and one brother. When I was growing up, my mom requested everyone to do part of the chores; for this reason, my brother did chores the same as I did.

One of the male participants said: some people have more possibilities and find it easier to reach their goals; this is not only gender-based. There are other issues behind equality. I think that the times when men had higher positions and earned better salaries than women have been left behind. Nowadays, many women have surpassed men. This view made everyone reflect about other social issues that mediate male and female relationships; they were also able to think about other kind of inequalities lived beyond gender differences.

Other participants said: I haven't had such an experience of being discriminated against during job search because I am still a student, but there are parents and grandparents who still hold marked gender discrimination. For example, my grandfather is of the idea that if he works he cannot wash his dish or his clothes. These ideas depend on age and the way they were raised. Women are commonly guilty of this chauvinist behavior and ideas when they do not allow men to do chores. This variety of experiences exposed participants to different viewpoints, and to expand their perceptions, thus, 
we could conclude that no matter the circumstances in which gender inequality takes place, this gap is to be bridged every day with more actions than discourse.

Figure 2. What would your parents say?

https://cdn4.vectorstock.com/i/1000x1000/25/03/playing- against-gender-stereotypes-vector-22012503.jpg

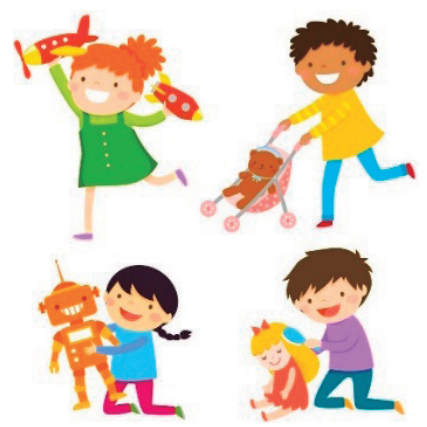

This image burst participants' desire to speak. They had very elaborate stories, which they were happy to share. Both female and male agreed on a marked difference between them and their parents or grandparents. The arguments given were embedded in narratives of how they had been raised, what the adults in their families had told them, and the informed decisions they were able to make today because of their social and cultural experiences outside their homes.

These stories could be classified as follows:

Gender roles beyond toys: I have told my daughter that she does not have to play with dolls just because she is a girl; not necessarily. Thinking that a boy will become girly because he plays with dolls is very close-minded and this makes women and men chauvinist. Once I saw a boy who wanted to play with a doll and his father told him to stop playing with that because he was not a gay person; the little kid was puzzled, he did not even understand what gay meant.

Gender roles encouraged by career choice: There are some gender roles in society which do not allow men to do what women do and vice versa. If a woman does something that is socially established to men, it is said that she is not feminine. The arts, for example, are mostly restricted to women. If a man does theater or dance, he might be stigmatized. Women studying engineering here at the university are said to be to be manlike.

What media sells: Kids also watch TV announcements that promote certain behaviors. Although these announcements do not completely reflect today's gender views, commerce stigmatizes women. Women are commonly offered to buy or given as presents 
things like irons, pots or washing machines, while men are invited to buy cars. A text message was sent to clients of the same supermarket; the husband received a message inviting him to buy beer at half price, while the wife received a message inviting her to buy detergent. For example, giving girls these dolls that are to be fed creates in them the awareness of women role just as the ones who nurse and raise children.

Discourse shaping behavior: Many people say that men don't cry; they have to be strong and women are weak. I think that this makes us generalize the behavior of men and women. The difference that is made in genders comes from childhood and is reflected when we are adults. We should raise our kids as equal. As grown-ups we are not treated equal either because if a man has more than one woman, he is a macho, but if a woman has more than one man she is ${ }^{* * *}$; thus I think that society stigmatizes.

The choice of toys given to kids in the image gave participants the opportunity to bring up realities they have experienced at home or with people they know. They are extremely aware of the influence that our family beliefs, discourse and media has on us; nonetheless, being at university has contributed to changing their mindset.

Figure 3. Where wouldn't you like to go?

https://image.slidesharecdn.com/icclesson-150610071542-lva1-app6892/95/icc-lesson-stereotypes-1-638. jpg? $\mathrm{cb}=1433920592$

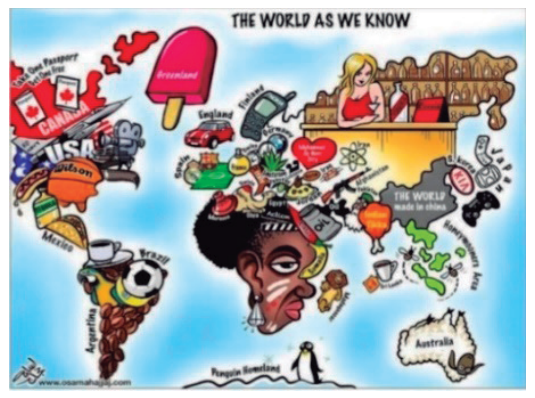

It was not easy for participants to answer this question because, as they mentioned, they were used to thinking of their favorite place to visit, not the opposite. When found on the spot, most of them stated that they would love to go anywhere, nevertheless, a few mentioned specific places they would not like to visit and provided reasons based on what they had heard other people say or mostly watched and read on the news. After listening to their arguments, we discussed about how media is or not likely to inform us in an objective and reliable manner, and how listening to only one part of the story, from an outsider's perspective, might not grant us with all the necessary elements to build an argument. Some of the examples provided were: 
I wouldn't like to go to Afghanistan because of what one perceives about war; nonetheless, it is the referent we have, what has been sold to us. Media has generalized that Colombians are traffic dealers or that Colombian women are easy. What happens in other countries could be the same, generalized because of the news we hear. I wouldn't go to the Middle East because of the way women are perceived there; they might not allow me to show my face or I will have to wear a dress; women are too subjugated there. I wouldn't like to go to USA because although this is a country with beautiful landscapes, it is ruled by bad people who want development at the expense of wars, poverty and pollution. Even though some of them would prefer not to visit certain places, they were also aware that much of this information had been subjectively provided to them, and it might not be completely true.

Other participants, on the opposite, affirmed: Not wanting to go to a place is not having the chance to know about their culture and what they have to show. When foreigners come to Colombia they fall in love with it because they find out that it is not just what media tells. We concluded that we know very little about other places; thus we should not draw conclusions based on a few facts or limited information we have received.

Figure 4. Who would you give the job to?

https://crestresearch.ac.uk/wp-content/uploads/2018/08/Using-Stereotypes-To-Prepare-For-Interviews1170x821.jpg
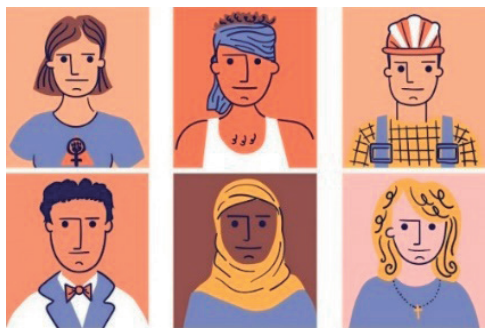

This image did not generate much discussion because it was hard for PTs to think as employers, however they were very open to difference and provided the following answers. I wouldn't judge people because of their physical appearance or culture, but will probably give them a test to know each person's skills for the job. I would also give the job to the most skillful person, no matter their beliefs. On the opposite, one of the PTs expressed: if image six is a catholic teacher, I would prefer to hire her, although they all deserve to be listened to and given the job opportunity. All in all, their perceptions about the situations illustrated in the images somehow relates to their initial education and family ties, but there are conscious decisions they have made in how they see others, 
which are the result of their university education and the new social roles established as part of the social groups they now belong to.

\section{Reading our campus}

To develop the project around campus, I gave PTs examples of ML practices and asked them to think about moments in which they had approached them. They were then encouraged to work collaboratively to find literacy expressions around campus. They designed and presented posters explaining the process lived, the reasons to choose the pictures taken, and the analysis of their findings. They chose to collect information on graffiti, clothing, messages in the girls' and boys' restrooms, food, ideology in street art, and expressions of knowledge and power. In this way, they could see our campus with new eyes, explore linguistic and sociocultural practices through ML, and make sense of the language they are learning.

Participants lived the knowledge process because they experienced the language through the expressions they found and because of the appropriation they made of those expressions in English. They applied when using the language to express their feelings along the project. They conceptualized by becoming aware of the environment around them, and by learning to read their campus with other eyes. They also analyzed by preparing a report and by reporting in front of the class, by answering questions from their partners and me, and by reflecting about their findings, stating a position of what they had experienced, as well as by acknowledging the learning derived from the project. Following, I present a series of pictures with the title, conceptualization and analysis done by participants:

Figure 5. What we have become

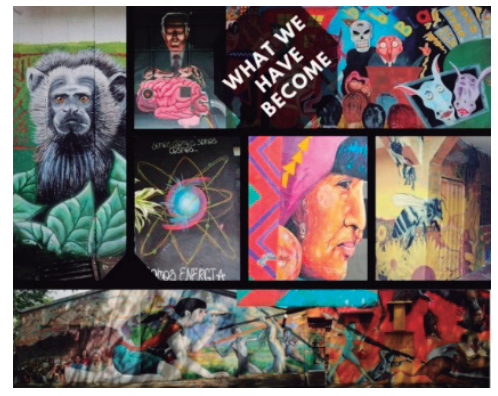

[Picture taken by PTs]

At the beginning of everything, we were just atoms, energy, we were part of something, we were one; through the years, we were advancing in everything, species, communities, civilizations, countries, but we have lost our culture and forgot our gods, 
mother nature. The industry to make money, has made us kill lots of species. Is this what we want for our future generations? The change we need is education.

Figure 6. Politician's plague

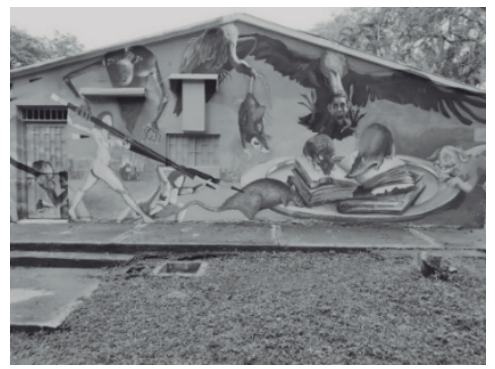

[Picture taken by PTs]

This piece of art expresses how the government works and the raw truth of the way the plague of important men does what they want with the Law and resources.

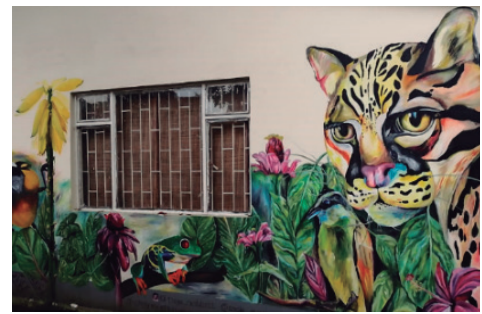

Figure 7. This is what we are

[Picture taken by PTs] This picture makes us think about nature, and how we act against this one, nature does not belong to us, we belong to nature.




Figure 8. Our restrooms talk

[Picture taken by PTs]

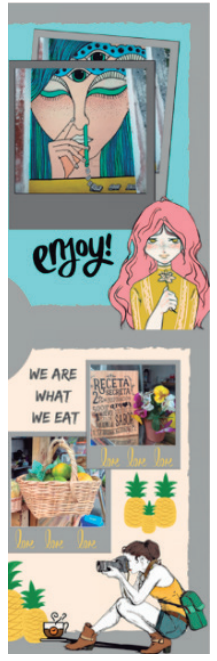

We think that people who write in the restrooms do it because they cannot express themselves outside. They have a lot to share or to complain about, but cannot do it because they are shy or they are afraid to talk in public. Women usually write about freedom, unity, and self-love. For example: Mujer no estás sola; No más feminicidios; Feminista resisite; Me amo como la tierra al sol. Men, on the other hand, talk about political issues or send messages to girls they like. For example: Congreso de los pueblos; vamos al poder; Nico te necesita.

Image 9. We are what we eat

[Picture taken by PTs]

There's stigma towards public university students; people usually think we are only interested in doing drugs and marching against everything, but most of us are just addicted to learning. We also have the graffiti in the entrance of the university which shows how there are many people outside, but only a few have the opportunity to enter. The picture of the fruits shows how our university is changing. Now students can have a proper diet and get income here.

The posters presentation, as seen in the pictures below, was an opportunity to know how each participant analyzed the campus and to also get to know places around us. 
Each group concentrated on diverse images and only a few coincided on taking pictures of the same. On top of that, PTs' analysis of the literacy expressions found on campus portrayed their sociocultural understanding of issues that they related to the reality lived by public universities and by the country as well. They reflected about inequality, starving children, war, insecurity, cultural values and roots lost, disconnection from mother nature, freedom, politics, unity, the need for acceptance or the desire to be oneself, inclusion of diversity, university students beyond stigma and the need for education.

There was reflection about the aspects mentioned through PTs' critical views. This exercise prompted discovery and empowerment in all participants who acknowledged having a new view of their campus now, thanks to the detailed reading they had done around it. Many issues were raised, which awoke several realities they were not aware of and that brought up the desire for changing what they did not find right.

\section{Survey}

Once participants presented the reading our campus projects, they completed a questionnaire whose purpose was to reflect about the experiences lived. I classified their answers and drew categories of analysis (Cohen et al., 2007) to establish commonalities and differences among their perceptions and gains.

In the first question, PTs talked about the type of literacy expressions and art pieces selected and the reason for choosing them. Among the most remarkable reasons to choose their projects, they mentioned the desire to learn about: variety, personality traits, people's likes and interests, meaning construction about reality, rebellion against the political and educational systems, empowerment and identity construction. PTs' topics of interest were aligned to the critical positions they commonly have in class, thus knowing and analyzing those topics gave them more elements to voice their perceptions.

The next question invited participants to analyze the literacy expressions or art pieces chosen. They expressed how any space can be owned through arts and how graffiti make walls talk. They also called for acceptance of our roots, open-mindedness, female empowerment, promote critical thinking and the study of literature. These topics encouraged reflection about the sociocultural reality we live in our campus and motivated thoughts about different ways of thinking and acting, which make part of one community.

Question three revealed the experience and challenges lived by PTs while developing their projects. They mentioned that it was pleasant and easy to find art expressions, mostly because they could choose the topics to talk about, but it was hard to talk to people or to take pictures of them; they felt uneasy at the beginning, but gained self-assurance as they learned how to do it. Among the positive experiences, 
they highlighted how people go against trends or have different viewpoints, which contributes to diversity. They also acknowledged how this project expanded their language skills in the process of developing, analyzing and reporting their findings.

Finally, participants reported the new perceptions of their campus developed as a result of having carried out this project. The main gains were in terms of making meaning out of what is written on our campus walls, in the expressions of people, in the need to voice their likes and interests through clothing; and in the ability to relate arts and literacy expressions to current live experiences, to reality.

\section{Conclusion and pedagogical implications}

A ML approach (Cope \& Kalantzis, 2009) is a bridge towards a socially-constructed intercultural experience in the language classroom because of the possibilities it brings to language learners to use diverse modes of communication, which unveil the cultural and social realities that surround them. Through a pedagogy of ML, PTs were able to develop a learning process that made them explore, reflect and use knowledge in the real world, thus having the opportunity to embrace diversity, reflect upon languecultural experiences and gain sociocultural understandings.

Bringing reality closer to PTs helped localize (Canagarajah, 2005) knowledge and build meaningful learning. This project supported on a theory of language that is socioculturally constructed and socioculturally experienced helped participants reflect upon their own sociocultural practices and uncover those of people around them. This is a way to reassure the notion that it is always possible to construct meaning and to make the language classroom a space for the recognition of our own cultural practices, the acknowledgement of the other, and the raising of tolerance. The knowledge process helped me organize the steps that I wanted PTs to walk through; by this means, I better engaged them in creating, experiencing, and living the language. 


\section{References}

Alvarez Valencia, J. A. (2016). Social networking sites for language learning: Examining learning theories in nested semiotic spaces. Signo y Pensamiento, 68, 66-84.

Amicucci, A. N. (2014). "How they really talk" Two students' perspectives on digital literacies in the writing classroom. Journal of Adolescent and Adult Literacy, 57(6), 483-491.

Areiza, H., Berdugo, M., \& Tejada, H. (2014). Una autopercepción de la multiliteracidad de un grupo de profesores y estudiantes de lenguas extranjeras de una universidad pública en Colombia. Folios, 40, 153-173.

Ausubel, D. (1963). The psychology of meaningful verbal learning. Grune \& Barton, D., \& Hamilton, M. (2000). Literacy practices. In D. Barton, M. Hamilton, \& R. Ivanic (Eds.), Situated literacies: Reading and writing in context (pp. 7-15). Routledge.

Boche, B. (2014). Multiliteracies in the classroom: Emerging conceptions of first-year teachers. Journal of language and literacy education, 10(1), 114-135.

Canagarajah, S. (2005) Reclaiming the local in language policy and practice. In A. Canagarajah (Ed.). Lawrence Erlbaum.

Carita, K., Mäkinen, M., \& Coiro. J. (2013). Rethinking academic literacies: Designing multifaceted academic literacy experiences for preservice teachers. Journal of Adolescent and Adult Literacy, 57(3), 223-232.

Clavijo, A. (2000). Una Mirada a la lectura y la escritura desde la práctica de los docentes en la escuela. Revista Científica. No. 2. Universidad Distrital.

Clavijo, A. (2003). Maestros innovadores en lectura y escritura. IDEPSED.

Clavijo, A. (2007). Prácticas innovadoras en lectura y escritura. Universidad Distrital.

Cohen, L. Manion, L., \& Morrison, K. (2007). Research methods in education (6 $6^{\text {th }}$ ed.). Routledge Falmer.

Cope, B., \& Kalantzis, M. (2000). Multiliteracies: The beginnings of an idea. In B. Cope, \& M. Kalantzis (Eds.), Multiliteracies: Literacy learning and the design of social futures (pp. 3-8). London: Routledge.

Cope, B., \& Kalantzis, M. (2009). Multiliteracies: New literacies, new learning. Pedagogies: An International Journal, 4(3), 164-195.

Corbett, J. (2010). Intercultural language activities. Cambridge University Press. 
Correa, D. (2010). Developing academic literacy and voice: challenges faced by a mature ESL student and her instructors. Profile, 12(1), 79-94.

Creswell, J. W. (2012). Educational research: Planning, conducting and evaluating quantitative and qualitative research $\left(4^{\text {th }} . E d\right)$. Pearson.

Cridland-Hughes, S. (2012). Literacy as social action in city debate. Journal of Adolescent and Adult Literacy, 56 (3), 194-202.

Curwood, J. S., \& Cowell, L. H. (2011). Poetry: Creating space for new literacies in the English curriculum. Journal of Adolescent and Adult Literacy, 55(2), 110-120.

De la Piedra, M.T. (2010). Adolescent worlds and literacy practices on the United States-Mexico border. Journal of Adolescent and Adult Literacy, 53(7), 575-584.

Dooley, K. (2009). Intercultural conversation: Building understanding together. Journal of Adolescent and Adult Literacy, 52(6), 497-506.

Freedman, L., \& Carver, C. (2007). Preservice teacher understandings of adolescent literacy development: Naive wonder to dawning realization to intellectual rigor. Journal of Adolescent and Adult Literacy, 50(8), 654-665.

Fukunaga, N. (2006). “Those anime students”: Foreign language literacy development through Japanese popular culture. Journal of Adolescent and Adult Literacy, 50(3), 206-222.

Gee, J. (1996). Social linguistics and literacies: Ideology in discourses. Routledge Falmer.

Guba, E.G., \& Lincoln, Y. S. (1994). Competing paradigms in qualitative research. In N. K. Denzin \& Y. S. Lincoln (Eds.), Handbook of qualitative research (pp. 105-117). Sage.

Hepple, E., Sockhill, M, Tan, A, \& Alford, J. (2014). Multiliteracies pedagogy: Creating claymations with adolescent, post-beginner English language learners. Journal of Adolescent and Adult Literacy, 58(3), 219-229.

Honebein, P. C. (1996). Seven goals for the design of constructivist learning environments. In B. G. Wilson (Ed.), Constructivist learning environments: case studies in instructional design. Educational Technology Publications.

Hua, Z. (2016). Identifying Research Paradigms. In Z. Hua (Ed.), Research methods in intercultural communication (pp. 3-22). Wiley-Blackwell.

Jacobs, G.E. (2013). Designing assessments: A multiliteracies approach. Journal of Adolescent \& Adult Literacy, 56(8), 623-626. 
Kalantzis, M., \& Cope, B. (2004). Designs for Learning. E-Learning, 1(1), 38-92

Kalantzis, M., \& Cope, B. (2008). Language education and multiliteracies. In S. May, \&

N. H. Hornberger (Eds.). Encyclopedia of language and education (2 ${ }^{\text {nd }}$. ed., pp. 195211). Springer.

Kim, G. M., \& Omerbašić, D. (2017). Multimodal literacies: Imagining lives through Korean dramas. Journal of Adolescent and Adult Literacy, 60(5), 557-566.

Knobel, M., \& Lankshear, C. (2007). The New Literacies Sampler. Peter Lang.

Kress, G. (2000). Multimodality. In B. Cope, \& M. Kalantzis (Eds.), Multiliteracies: literacy learning and the design of social futures (pp. 182-202). Routledge.

Kress, G. (2010). Multimodality: A social semiotic approach to contemporary communication. Routledge.

Kress, G., \& Van Leeuwen, T. (2001). Multimodal Discourse: The Modes and Media of Contemporary Communication. Oxford University Press.

Kumaravadivelu, B. (2001). Towards a postmethods pedagogy. TESOL Quarterly, 35(4), 537-560.

Kumaravadivelu, B. (2006). Understanding language teaching: From method to postmethod. Lawrence Erlbaum Associates.

Losada, J., \& Suaza, D. (2018). Video-mediated listening and multiliteracies. Colombian Applied Linguistics Journal, 20(1), 11-24.

Luke, C. (2000). Cyber-schooling and technological change: multiliteracies for new times.In B. Cope, \& M. Kalantzis (Eds.), Multiliteracies: Literacy learning and the design of social futures (pp. 3-8). Routledge.

Medina, R., Ramirez, M., \& Clavijo, A. (2015). Reading the community critically in the digital age: A multiliteracies approach. In P. Chamness Miller, M. Mantero, \& H. Hendo (Eds.). ISLS Readings in Language Studies (Vol. 5., Pp. 45-66). International Society for Language Studies.

Meng, X. (2016). A pedagogy of multiliteracies into practice: A case study in one grade one literacy classroom (Doctoral thesis, University of West Ontario, Canada). Retrieved from https://ir.lib.uwo.ca/cgi/viewcontent.cgi?article=5409\&context=etd

Merriam, S. B. (2009). Qualitative research: A guide to design an implementation. Jossey-Bass. 
Michelson, K. (2018). Teaching culture as a relational process through a multiliteraciesbased global simulation. Language, Culture and Curriculum, 31(1), 1-20.

Michelson, K., \& Alvarez Valencia, J. A. (2016). Study abroad: Tourism or education? A multimodal social semiotic analysis of institutional discourses of a promotional website. Discourse and Communication, 10(3), 235-256.

Michelson, K., \& Dupuy, B. (2014). Multi-storied lives: Global simulation as an approach to developing multiliteracies in an intermediate French course. L2 Journal, 6, 21-49.

Mora, R. A. (2011). Tres retos para la investigación y formación de docentes en inglés: reflexividad sobre las creencias y prácticas en literacidad. Revista Q, 5(10), 1-20.

Mora, R. A. (2012). Literacidad y el aprendizaje de lenguas: Nuevas formas de entender los mundos y las palabras de nuestros estudiantes: Revista Internacional Magisterio Educación y Pedagogía, 58, 52-56.

Mora, R. A. (2014) Critical literacy as policy and advocacy: Lessons from Colombia. Journal of Adolescent and Adult Literacy, 58(1) 16-18.

Mora, R. A. (2015). City literacies in second languages: New questions for policy and advocacy. Journal of Adolescent and Adult Literacy, 59(1), 21-24.

Mora, R. A. (2016). Translating literacy as global policy and advocacy. Journal of Adolescent and Adult Literacy, 59(6), 647 - 651.

Nieto, Y. (2018). Promoting the use of local literacies in EFL Pre-service teachers to inspire their teaching practice. Colombian Applied Linguistics Journal, 20(2), 263 273.

Olthouse, J.M. (2013). Multiliteracies theory and gifted education: Creating 'smart spaces' in the language arts classroom. Gifted Child Today, 36(4), 246-253.

O'Rourke, M. (2015). Multiliteracies for $21^{\text {st }}$ century schools. Australian National Schools Network, Faculty of Education, University of Technology, Sydney, Lindfield, N.S.W

Patton, M. Q. (2002). Qualitative, research \& evaluation methods. Sage publications Inc.

Perry, K. (2012). What is literacy? A critical overview of sociocultural perspectives. Journal of Language and Literacy Education, 8(1), 50-71.

Rincon, J., \& Clavijo, A. (2016). Fostering EFL learners' literacies through local inquiry in a multimodal experience. Colombian Applied Linguistics Journal, 18(2), 67-82. 
Rowsell, J., \& Collier, D. R. (2017). Researching multimodality in language and education. In K.A. King, Y. J. Lai, \& S. May (Eds.), Research Methods in Language and Education. Encyclopedia of Language and Education ( $3^{\text {rd }}$ ed., p.p. 311-324). Springer.

Sharkey, J. (2012). Community-based pedagogies and literacies in language teacher education: Promising beginnings, intriguing challenges. Ikala, 17(1), 9-13.

Street, B. (2013, September 27). Multimodality and new literacy studies: What does it mean to talk about 'texts' today? King's College London. Online Talk for Universidad Pontificia Bolivariana: Medellin-Colombia.

The New London Group. (1996). A Pedagogy of Multiliteracies: Designing Social Futures. Harvard Educational Review, 66 (1), 60-92.

\section{Author}

${ }^{*}$ Angela Castro has a B.A in Modern Languages, a Specialization in Pedagogy of Reading and Writing, and an M.A in TESOL. She is a fourth-year PhD student at Universidad del Valle, and a professor at Universidad del Cauca. Her research interests include literacy studies and intercultural communication.

ORCID: http://orcid.org/0000-0001-6675-0937

How to reference this article: Castro-Garcés, A. Y. (2021). Awakening Sociocultural Realities in Pre-service Teachers through a Pedagogy of Multiliteracies . GIST - Education and Learning Research Journal, 22(1), 173-197. https://doi.org/10.26817/16925777.844 